\title{
GAMBARAN AKTIVITAS LISTRIK JANTUNG PASIEN RAWAT INAP DENGAN CONGESTIVE HEART FAILURE (CHF) DI IRINA F-JANTUNG RSUP PROF DR. R. D. KANDOU MANADO
}

\author{
${ }^{1}$ I Made S. K. Raka \\ ${ }^{2}$ Vennetia R. Danes \\ ${ }^{2}$ Wenny Supit \\ ${ }^{1}$ Kandidat Skripsi Fakultas Kedokteran Universitas Sam Ratulangi Manado \\ ${ }^{2}$ Bagian Fisika Fakultas Kedokteran Universitas Sam Ratulangi Manado \\ Email: r.stalen@yahoo.com
}

\begin{abstract}
Congestive Heart Failure (CHF) occurs when the heart is unable to pump the blood to fulfill body's need of blood related to tissue metabolism. Electrical activity of the heart is the state in which the heart has to pump the blood and to contract, triggered by an action potential that spreads through the membrane of muscle cells. Electrocardiogram (ECG) is generated by the electrical activity of the heart muscle. It is a recording of a heart condition obtained by placing electrodes on the body. This study aimed to describe the heart electrical activity of patients with congestive heart failure. This was a retrospective descriptive study. The population was all patients hospitalized in Irina F Cardiac Department of Prof. Dr. R. D. Kandou Hospital Manado. Samples were ECG recordings of all patients with CHF hospitalized at Irina F Cardiac Department of Prof. Dr. R. D. Kandou Hospital Manado during Desember 2012-January 2013. The results showed that hypertensive heart disease (HHD) was the most frequent cause of CHF (45.5\%). Meanwhile, CHF due to old myocardial infarction (OMI) was rare (18.2\%). Conclusion: The most common cause of CHF among hospitalized patients at Irina F Cardiac Department of Prof. Dr. R. D. Kandou Manado was HHD. ECG of patients with CHF et causa HHD showed an overview of normal heart rhythm and tachycardia, PR interval and a normal QRS complex, left axis deviation, ST segment elevation, depression on different leads, and pathological Q.
\end{abstract}

Keywords: congestive heart failure, electrical activity, electroCardiogram

\begin{abstract}
Abstrak: Gagal jantung kongestif atau congestive heart failure (CHF) terjadi bila jantung tidak dapat memompakan darah untuk memenuhi kebutuhan darah dalam tubuh untuk metabolisme jaringan. Aktivitas listrik jantung yaitu keadaan dimana jantung dapat memompa darah, jantung harus berkontraksi yang dicetuskan oleh potensial aksi yang menyebar melalui membran sel-sel otot. Elektrokardiogram (EKG) adalah suatu sinyal yang dihasilkan oleh aktifitas listrik otot jantung. EKG ini merupakan rekaman informasi kondisi jantung yang diambil dengan memasang elektroda pada badan seseorang. Penelitian ini bertujuan untuk mengetahui gambaran aktivitas listrik jantung pada pasien gagal jantung kongestif. Penelitian ini menggunakan metode deskriptif retrospektif. Populasi ialah semua pasien rawat inap di Irina F Jantung RSUP Prof. Dr. R. D. Kandou Manado. Sampel ialah rekaman EKG semua pasien dengan diagnosis gagal jantung kongestif di Irina F Jantung RSUP Prof. Dr. R. D. Kandou Manado selama bulan Desember 2012- Januari 2013. Hasil penelitian memperlihatkan bahwa penyebab gagal jantung kongestif yang terbanyak ialah hypertensive heart disease (HHD) (45,5\%), dan yang paling sedikit ialah old myocardial infarction (OMI) (18,2\%). Simpulan: Penyebab terbanyak gagal jantung kongestif pada pasien rawat inap di
\end{abstract}


Irina F-Jantung RSUP Prof. Kandou Manado ialah HHD. EKG pada pasien CHF et causa HHD memberikan gambaran irama jantung yang normal dan juga takikardi, interval PR dan kompleks QRS normal, aksis deviasi kekiri, elevasi dan depresi segmen ST pada sadapan yang berbeda, dan Q patologik.

Kata kunci:gagal jantung kongestif, aktivitas listrik jantung, elektrokradiogram

Gagal jantung kongestif atau Congestive Heart Failure (CHF) terjadi bila jantung tidak dapat memompa darah untuk memenuhi kebutuhan darah dalam tubuh untuk metabolisme jaringan. ${ }^{1}$

Pada tahun 2008 diperkirakan sebanyak 17,3 juta kematian disebabkan oleh penyakit kardiovaskuler. Lebih dari 3 juta kematian tersebut terjadi sebelum usia 60 tahun dan seharusnya dapat dicegah. Kematian "dini” yang disebabkan oleh penyakit jantung terjadi berkisar sebesar 4\% di negara berpenghasilan tinggi sampai dengan $42 \%$ terjadi di negara berpenghasilan rendah. ${ }^{2}$ Faktor risiko terpenting untuk CHF ialah penyakit arteri koroner (PJK) dan penyakit jantung iskemik. Hipertensi merupakan faktor risiko terpenting kedua untuk CHF. Faktor risiko lainnya terdiri dari kardiomiopati, aritmia, gagal ginjal, diabetes, dan penyakit katup jantung. ${ }^{3}$

Aktivitas listrik jantung yaitu keadaan dimana jantung dapat memompakan darah dan jantung harus berkontraksi yang dicetuskan oleh potensial aksi yang menyebar melalui membran sel-sel otot. Jantung berkontraksi secara berirama akibat potensial aksi yang ditimbulkannya sendiri, disebut sebagai otoritmisitas. ${ }^{4}$

Elektrokardiogram (EKG) adalah suatu sinyal yang dihasilkan oleh aktifitas listrik otot jantung. EKG ini merupakan rekaman informasi kondisi jantung yang diambil dengan memasang elektroda pada badan. Rekaman EKG ini digunakan oleh dokter untuk menentukan kondisi jantung dari pasien. Sinyal EKG direkam menggunakan perangkat elektrokardiograf. ${ }^{4}$

Elektrokardiogram mempunyai banyak manfaat, baik untuk diagnosis, manajemen, dan terapi lanjut dari pasien dengan gagal jantung kongestif. Gambaran EKG pada pasien gagal jantung kongestif dapat menunjukkan berbagai macam kelainan. Terkadang pasien dengan gagal jantung kongestif dapat memberikan gambaran EKG normal, atau hanya menunjukkan sinus takikardi tanpa kelainan lainnya. Secara umum, hasil EKG pada pasien gagal jantung kongestif memberikan gambaran hipertrofi ventrikel kiri (LVH), semua jenis aritmia atrium dan ventrikel, blok konduksi atrio-ventrikular dan intraventrikel, adanya iskemia dan/atau infark miokard, hipertrofi ventrikel kanan dan kiri, serta kelainan atrium kanan. Contoh klasik kelainan EKG yang berhubungan dengan gagal jantung kongestif ialah hipertrofi ventrikel kiri, abnormalitas atrium kiri, dan fibrilasi atrium. $^{5,6}$

\section{METODE PENELITIAN}

Penelitian ini menggunakan metode deskriptif retrospektif untuk mengetahui gambaran aktivitas listrik jantung pasien dengan gagal jantung kongestif dengan menggunakan gambaran elektrokardiogram. Penelitian dilakukan di Irina F RSUP Prof. Dr. R. D. Kandou Manado selama periode Desember 2012-Januari 2013. Populasi penelitian ialah semua pasien rawat inap di Irina F. Sampel ialah semua data yang didapat dari hasil rekaman EKG pasien CHF di Irina F. Teknik pengumpulan data yaitu pengumpulan data sekunder yang diperoleh dari hasil rekam medis di Irina F-Jantung RSUP Prof Kandou Manado.

\section{HASIL PENELITIAN}

Data distribusi jenis kelamin pasien yang diambil menjadi sampel semuanya laki-laki yaitu 11 pasien (100\%). Pada 
distribusi umur pasien, terbanyak pada golongan usia 61-70 tahun (45,5\%), sedangkan yang paling sedikit golongan 40-50 tahun $(9,1 \%)$.

Pada distribusi berdasarkan penyebab CHF yang terbanyak ialah CHF dengan penyebab Hypertensive Heart Disease (HHD) (45,5\%), yang paling sedikit CHF dengan penyebab OMI (18,2\%).

EKG pada pasien CHF et causa HHD memberikan gambaran irama jantung yang normal dan juga takikardi, interval PR dan kompleks QRS normal, aksis deviasi kekiri, elevasi dan depresi segmen ST pada sadapan yang berbeda, serta $\mathrm{Q}$ patologik. EKG pada pasien CHF et causa coronary arterial disease (CAD) memberikan gambaran irama jantung normal dan juga takikardi, interval PR dan kompleks QRS normal, aksis normal, elevasi segmen ST, dan $Q$ patologik.

EKG CHF et causa OMI memberikan gambaran irama jantung normal, interval PR dan kompleks QRS normal, aksis normal, dan Q patologis.

\section{BAHASAN}

Pada penelitian ini didapatkan jenis kelamin pasien semuanya laki-laki (100\%), sedangkan jenis kelamin perempuan tidak ada.

Umur pasien yang terbanyak yaitu pada golongan usia 61-70 tahun 45,5\%, kemudian 71-80 tahun 27,3\%, 51-60 tahun $18,2 \%$, sedangkan yang paling sedikit golongan $40-50$ tahun $9,1 \%$.

Pada tahun 2008 diperkirakan sebanyak 17,3 juta kematian disebabkan oleh penyakit kardiovaskuler. Lebih dari 3 juta kematian tersebut terjadi sebelum usia 60 tahun dan seharusnya dapat dicegah. ${ }^{2}$ Faktor risiko terpenting untuk CHF ialah PJK, disusul oleh hipertensi, dan lainnya yaitu penyakit arteri coroner dengan penyakit jantung iskemik. Hipertensi adalah factor resiko terpenting kedua untuk CHF. Factor resiko lain terdiri dari kardiomiopati, aritmia, gagal ginjal, diabetes, dan penyakit katup jantung. ${ }^{3}$
Berdasarkan hasil penelitian, EKG pada pasien CHF et causa HHD memberikan gambaran irama jantung yang normal atau takikardi, interval PR dan kompleks QRS normal, aksis deviasi kekiri, elevasi dan depresi segmen ST pada sadapan yang berbeda, terdapat LVH (left ventricular hypertrophy), iskemik miokard, dan Q patologik, dan juga low voltage (hantaran yang kecil ).

\section{SIMPULAN}

Berdasarkan hasil penelitian dan bahasan dapat disimpulkan:

1. Penyebab terbanyak gagal jantung kongestif pada pasien rawat inap di Irina F-Jantung RSUP Prof. Dr. R. D. Kandou Manado ialah HHD

2. EKG pada pasien CHF et causa HHD memberikan gambaran irama jantung yang normal dan juga takikardi, interval PR dan kompleks QRS normal, aksis deviasi kekiri, elevasi dan depresi segmen ST pada sadapan yang berbeda, serta Q patologik.

3. EKG pada pasien CHF et causa CAD memberikan gambaran irama jantung yang normal dan juga takikardi, interval PR dan kompleks QRS normal, aksis normal, elevasi segmen ST, dan Q patologik.

4. Gambaran EKG CHF et causa OMI memberikan gambaran irama jantung normal, interval PR dan kompleks QRS normal, axis normal, dan Q patologik.

\section{DAFTAR PUSTAKA}

1. Lynn BC, Sowden LA. Buku Saku Keperawatan pediatri. Edisi 5. Jakarta:EGC, 2009.

2. O'Brien T. Congestive Heart Failure.South Carolina: Medical University of South Carolina: 2006. Available from URL: http://www.emedicinehealth.com/cong estive_heart_failure/article_em.html

3. Nurdjanah S. Sirosis Hati. In: Sudoyo, Aru $\mathrm{W}$, et al, editors. Buku Ajar Ilmu Penyakit Dalam Jilid I (4th ed.). Jakarta: Pusat Penerbitan Departemen Ilmu Penyakit Dalam FKUI, 2006; p. 
Raka, Danes, Supit: Gambaran aktivitas listrik...

443-8.

4. Danes VR, Harrap SB, Ellis JA, Griffiths CD, Jones EF, Delbridge LMD. The hypertrophic heart rat: a new normotensive model of genetic cardiac and cardiomyocyte hypertrophy. Physiol. Genomic. 2002;9:43-8.

5. Basset AL, Golband H. Chronic partial occlusion of the pulmonary artery in cats. Changes in ventricular action potential configuration during early hypertrophy. Circ.Res. 1973;32:15-26.

6. Danes VR, Domenighetti AA, Curl CL, Favaloro JM, Proietto J, Delbridge LMD. Targeted GLUT-4 deficiency in the heart induces cardiomyocyte hypertrophy and impaired contractility linked with $\mathrm{CA}^{2+}$ and proton flux dysregulation. J Mol Cell Cardiol. 2010;663-72. 